UDC $65.05+628.23$

D. F. Goncharenko ${ }^{1}$, Dr. Sc. (Tech.), Prof., orcid.org/0000-0003-1278-0895,

A. V. Ubyivovk ${ }^{1}$, Cand. Sc. (Tech.), Assoc. Prof., orcid.org/0000-0001-5319-9429,

O. O. Garmash ${ }^{2}$, Cand. Sc. (Tech.), orcid.org/0000-0001-6155-6254, M.P. Gorokh ${ }^{3}$, orcid.org/0000-0003-4030-9558
DOI: $10.29202 /$ nvngu/2019-1/14

1 - Kharkiv National University of Civil Engineering and Architecture, Kharkiv, Ukraine, e-mail: gonch@kstuca.kharkov.ua 2 - Stock Company "Yuzhspetsatomenergomontazh", Kharkiv, Ukraine, e-mail: usaem.ot@ukr.net

3 - "Vodokanal" Public Utility, Kharkiv, Ukraine, e-mail: hkov_invest@yahoo.com

\title{
RESTORATION OF URBAN UNDERGROUND WORKINGS USING SECONDARY POLYMER COMPOSITES
}

Currently, the underground infrastructure of large cities of Ukraine is significantly worn out as a result of longterm operation, inefficient solutions for protecting the structures from corrosive environmental influences, poor quality of materials and construction and assembly operations during erection. Restoration of operational performances, reliability and durability of elements of the underground network of workings is a costly and difficult technical and organizational problem. However, its solution is needed to prevent accidents including those with serious environmental and economic consequences. Existing modern technologies for performing work on restoring the functioning of the underground infrastructure of large cities, the materials used to restore them allow solving these problems with different efficiency. But in addition, the need to reduce restoration costs through the use of polymer materials, improve technological solutions and solve environmental problems of megalopolises is a relevant area of research.

Purpose. Taking into account the accumulated operating experience to develop geomechanical models and, on their basis, propose technical solutions for restoration of serviceability, reliability and durability of extended workings of the city underground network.

Methodology. Methodology includes full-scale investigation of urban underground workings in operation, experimental analysis of the polymer material in corrosive environment, and numerical simulation of strain-stress state of the protective lining at the stages of construction and operation.

Findings. The results indicate high efficiency of the considered polymer material under the influence of corrosive environment; numerical simulation of the stress-strain state of the protective lining allows determining the optimal geometric parameters of the lining elements depending on the mechanical properties of the material and distinctive features of its assembly technology.

Originality. The technology of restoration of support in extended underground workings is proposed and the possibility of using a composite material based on secondary polymer resources is justified.

Practical value. The cost-effective solution of the problem of restoration of lining of the extended underground workings (tunnels) through the use of products of secondary polymer materials is involved. Use of products of these materials in restoration of supports of extended underground workings (tunnels) has significant economic and environmental effect and also makes it possible to restore hard-to-reach areas.

Keywords: urban underground workings, geomechanical models; destruction of support; protective lining;products of secondary composite polymer materials

Introduction. To date, the underground infrastructure systems of large cities of Ukraine consist of significant in length and depth sections of sewer tunnels, which were laid by trenchless method using blade shields providing the tunnel diameters of $2.1 ; 2.56 ; 3.2 ; 3.7$ and $4 \mathrm{~m}$ [1].

The infrastructure of Ukrainian cities including construction of underground water disposal networks was built in the period of intensive industrial development that took place in the second half of the twentieth century. During that period, in Kharkiv over $50 \mathrm{~km}$ of deep sewer tunnels were put in commission; for their maintenance about a hundred of inspection shafts and backdrop manholes were built according to the existing regulatory requirements [2].

To date, the usage period of these networks is more than 40 years. Complying continuous water disposal de-

(c) Goncharenko D. F., Ubyivovk A. V., Garmash O. O., Gorokh M. P., 2019 mands under no backup sites of sewer tunnels, due to long-term operation, violations of the technology during construction, as well as insufficient corrosion resistance of the used materials, sewer tunnels show evidence for significant physical deterioration resulting in emergency situations related to destruction of tunnel sections, damage of structures of inspection shafts, stilling pools, and others.

Rapidly deteriorating engineering status of the underground working networks, along with a decrease in their operational characteristics, causes accidents occurring more and more frequently and requires substantial financial expenses for emergency procedures and local repair.

It is a fair assumption to say that the engineering status of the underground drainage systems of large cities of Ukraine is unsuitable for normal operation, and some structures or sections of the networks are hazardous and threaten not only economic damage, but also major ac- 
cidents with significant environmental and social consequences [3].

The technologies of restoration of supports of underground workings developed to date involve using various materials and technological solutions, which indicates the multifactorial nature of the problem of their restoration and, consequently, impossibility of developing a universal restoration technology. Technical problems caused by emergency situations are not always effectively solved due to the well-known methods of sliplining and restoration of the networks. Thus, developing the effective and universal technological and constructive solutions to restore the operational suitability, reliability and durability of underground sewage networks should be considered an urgent independent task, which is a necessary component of a comprehensive solution for the problem under consideration.

Analysis of the recent research and publications. Domestic and foreign experience in restoration of underground infrastructure networks and protection of supporting structures of tunnels is presented in the literature with technical solutions involving construction of protective lining of supporting structures that is resistant to aggressive environment, as well as with the measures to restore the bearing capacity of tunnel support structures when it is significantly reduced $[2,4]$.

Modern development of the industry of building materials, products and technologies provides ample opportunities for implementation of various technical and technological solutions for sliplining of underground sewage networks using various types of pipes [5, 6], as well as polyethylene sheets [2] to ensure protection of reinforced concrete structures and pipes [7] during implementation of restoration measures.

Behavior of polymer materials (in particular, polyethylene) under the conditions of prolonged exposure to chemically aggressive environment and microbiological effects is well studied both in laboratory experiments and within the framework of practice in experimental developments [2].

Unsolved aspects of the problem. For tunnels whose internal dimensions make them accessible for workers if sliplining by using pipes is limited or impossible (in cramped space with insufficient overall dimensions or inconvenient location of shafts, and others), there is practically no possibility to assemble the protective lining of polymer coating. Thus, in modern practice, there are no alternative methods that allow using secondary polymer compound products to restore the protective lining under the conditions described above including the tunnels in operation.

Objectives. Taking into account the existing domestic and international experience in operating and restoring the supports in the systems of underground workings, to develop geomechanical models and justify on their basis parameters of the supporting structure providing an effective constructive and technological alternative for restoring the operational suitability, reliability and durability of sewer tunnels.

Methodology of the study. The development of the method for sewer tunnel restoration using the recycled polymer composite elements includes the following steps and corresponding research methods:

- full-scale condition surveys of urban underground workings (sewer tunnels) which have been in long-term operation - for assessing their actual condition and operational suitability;

- experimental research methods - for assessing the corrosion resistance of composite materials;

- numerical methods (finite-element method) implemented in design software packages - for developing the geomechanical models and assessing the strength of the protective lining (support) at all stages of its design and operation.

Presentation of the main research. Considering the accumulated domestic and global experience in restoration of the structures of underground wastewater networks and their anti-corrosion protection, the proposed technical solutions for alternative methods of restoration should meet the following requirements:

- technological effectiveness of manufacturing the protective elements;

- simple installation and possibility to use the technology in hard-to-reach areas;

- adaptability of the technology of manufacturing the products to different requirements in terms of geometric parameters and strength characteristics of the protective lining being made;

- reliability and durability;

- ensuring the required corrosion protection of the load-bearing structures of the tunnel lining;

- environmental friendliness of the technology;

- competitive economic efficiency.

In recent years, sliplining of the sewer networks in Ukraine has been carried out using various types of pipes made of polymers (fiberglass, polyethylene). Use of polyethylene sheets with anchor ribs (so-called profiled polyethylene) has also become widespread for protection of reinforced concrete structures. Despite the numerous positive qualities of this material such as versatility, usability, and high resistance to corrosive environment, its significant disadvantages include high cost.

The increasing volumes of manufacturing and commercial polymer wastes makes it possible to reuse them based on the environmental and economic considerations, thus providing competitiveness of products of secondary polymer composite materials (SPCMs) in comparison with primary cycle products [8].

SPCMs possess a number of properties that determine the possibility of their use as protective coatings:

- high corrosion resistance;

- low cost compared to primary polymer materials.

Performances of SPCM are presented in Table 1.

Selection of SPCM for protective coating has grounds, which is confirmed by test results of the model sample (Fig. 1) and the concrete sample coated with polymer compound in the corrosive environment.

The compressive strength tests of the samples showed no reduction in strength of concrete in comparison with the original strength of the check samples, which ranged from 25 to $27 \mathrm{MPa}$. 
Table 1

Main characteristics of SPCM

\begin{tabular}{|l|c|c|}
\hline \multicolumn{1}{|c|}{ Characteristic } & Unit & Range of values \\
\hline Impact Strength & $\mathrm{kJ} / \mathrm{m}^{2}$ & $31 / 43-39 / 68$ \\
\hline $\begin{array}{l}\text { Transverse } \\
\text { Rupture Stress }\end{array}$ & $\mathrm{MPa}$ & $\begin{array}{c}8.7 / \text { rupture is reached }- \\
8.7 / \text { rupture is reached }\end{array}$ \\
\hline Melt Flow Index & $\mathrm{G} / 10 \mathrm{~min}$ & $0.87-2.37$ \\
\hline $\begin{array}{l}\text { Stress Cracking } \\
\text { Resistance }\end{array}$ & $\mathrm{h}$ & $>12$ \\
\hline
\end{tabular}

Note: numerators show the values for model sample with a notch groove; denominators show the values for model sample without a notch groove

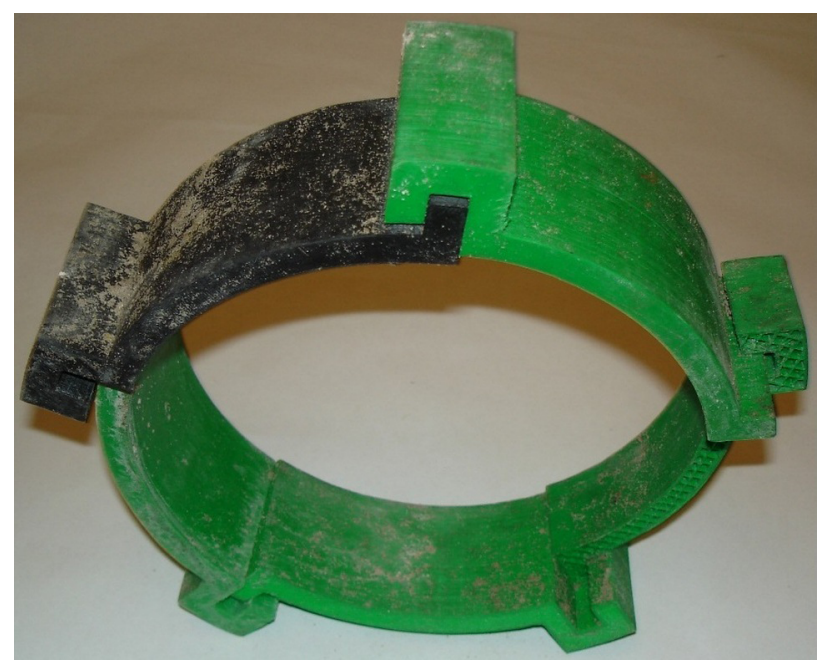

Fig. 1. A protective lining model sample with longitudinal joints of the clutch after testing in corrosive environment

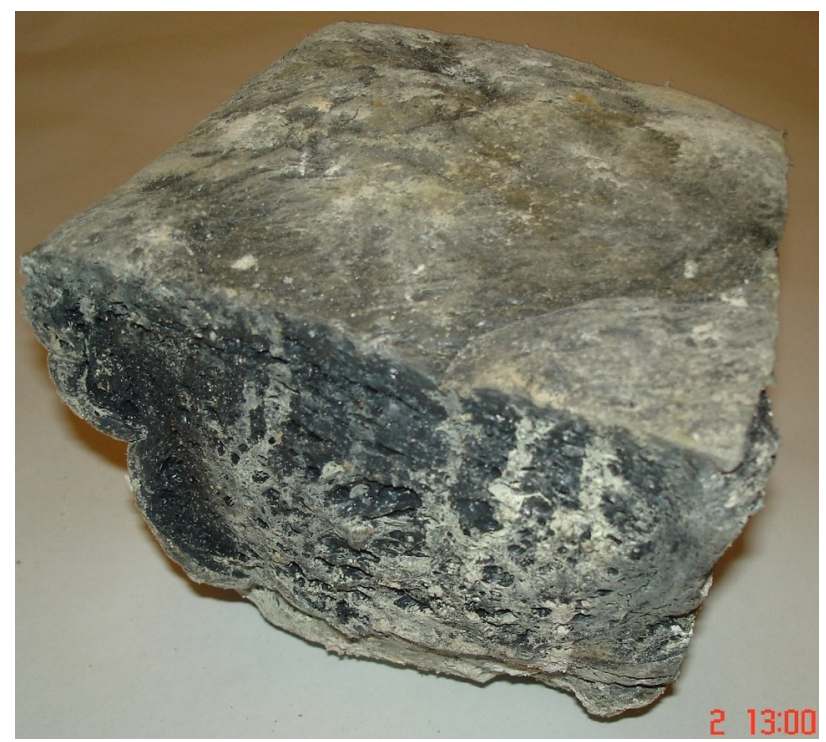

Fig. 2. A sample of concrete with applied polymer compound coat based on the secondary materials after testing under the corrosive environment conditions in camera No. 2 of the sewer in Kharkiv
Calculation of the tunnel protective lining of composite polymer elements was done on the basis of a geomechanical model of two-layer lining deformed together with the surrounding mass to determine the required thickness of the protective lining and to develop the restoration technology for sewer tunnel with the design diameter of $1840 \mathrm{~mm}$. Initial statements accepted for the calculations:

1. Load-carrying capability of the reinforced concrete lining is taken for granted.

2. The following loading conditions as controlling cases for protective lining made of polymer elements are accepted:

a) external hydrostatic pressure of concrete mix during concreting of the tube spaces;

b) external hydrostatic pressure of the water which is filtered in the ground and penetrates through the reinforced concrete lining.

The calculation was performed by the finite-element method by means of SCAD software package.

The design model is a fragment of cylindrical shell with the length of $1.2 \mathrm{~m}$ and the diameter of $1.8 \mathrm{~m}$ consisting of flat quadrangular finite shell elements (type FE - 44) with dimensions $0.12 \cdot 0.12 \mathrm{~m}$.

The boundary conditions are taken in the form of bonds and associations of displacement (by introducing rigid solids) in the nodes located on perimeter of the end sections of the considered area that corresponds to the articulated joint of adjacent areas of the protective lining with temporary (for the period of concreting) reinforcement with rigid diaphragms.

The following parameters of final elements in the design model are accepted:

- thickness - $30 \mathrm{~mm}$;

- modulus of elasticity $E=1.4 \cdot 10^{4} \mathrm{MPa}$;

- Poisson's ratio $v=0.3$.

Tensile strength for polymer material is assumed to be $170 \mathrm{MPa}$.

Simulation data in the form of isofields of displacements and forces are shown in Figs. 3-10.

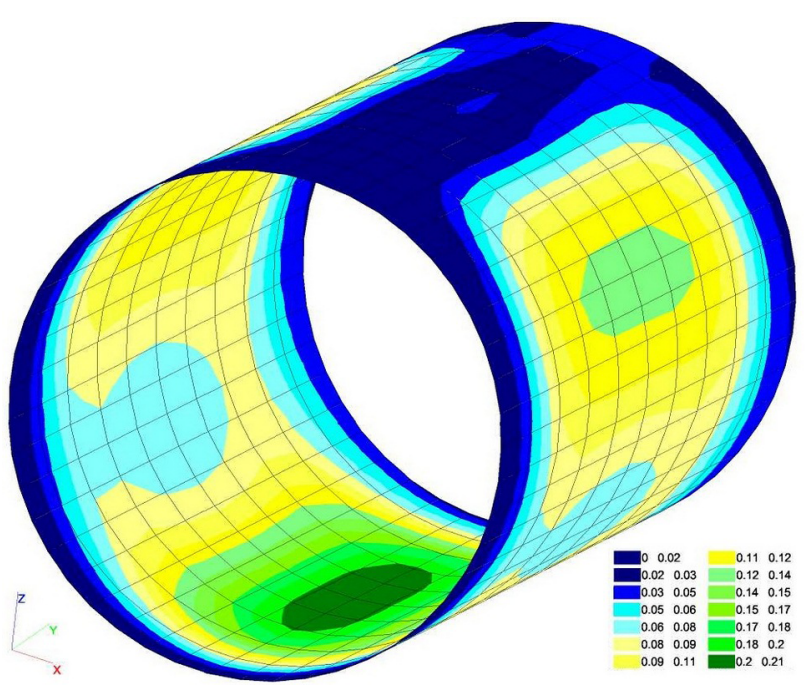

Fig. 3. Absolute displacements of reinforced lining (deviations from the initial position) during concreting, $\mathrm{mm}$ 


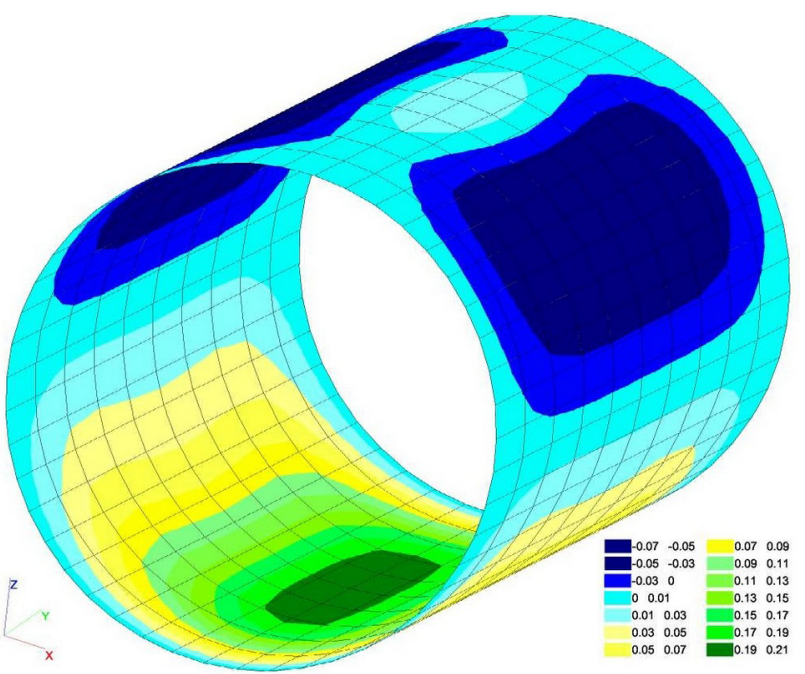

Fig. 4. $Z$ axis displacements of reinforced lining during concreting, $\mathrm{mm}$

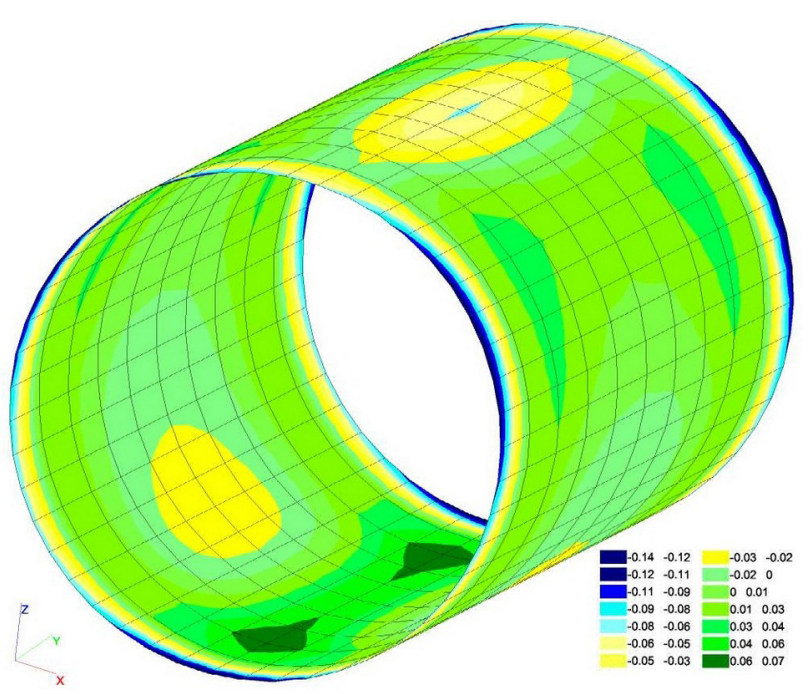

Fig. 5.MX torques in the structure of reinforced lining during concreting, $\mathrm{kNm} / \mathrm{m}$

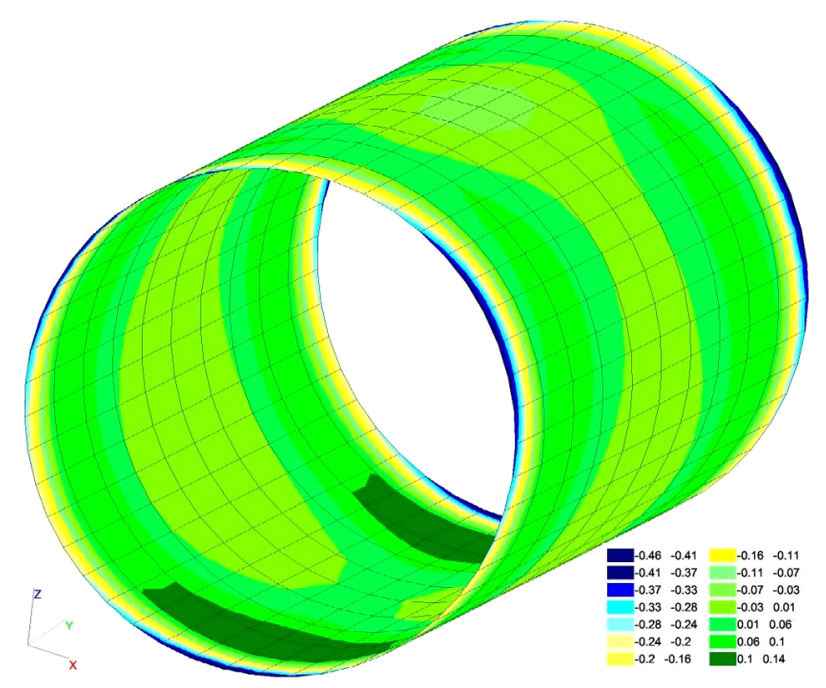

Fig. 6. MY torques in the structure of reinforced lining during concreting, $\mathrm{kNm} / \mathrm{m}$

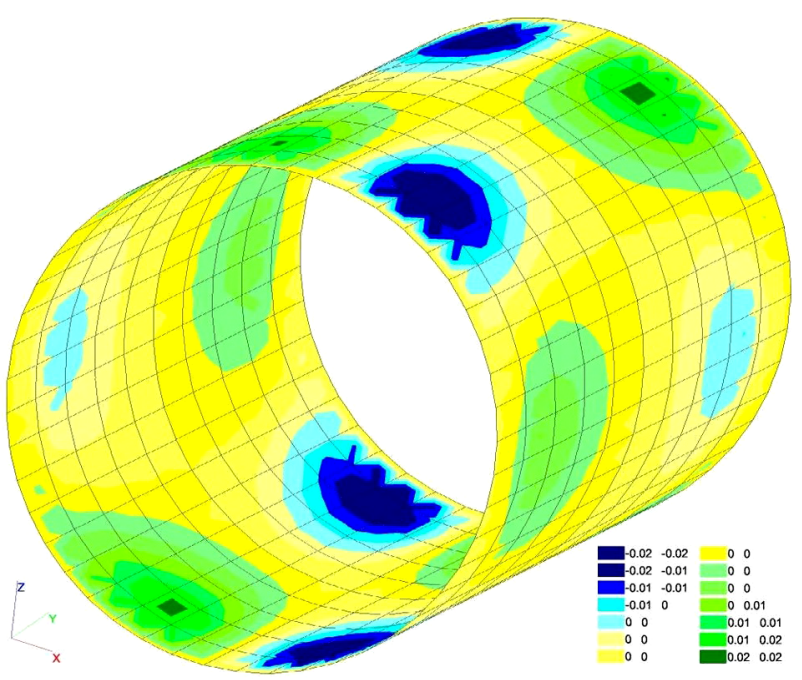

Fig. 7. MXY torques in the structure of reinforced lining during concreting, $\mathrm{kNm} / \mathrm{m}$

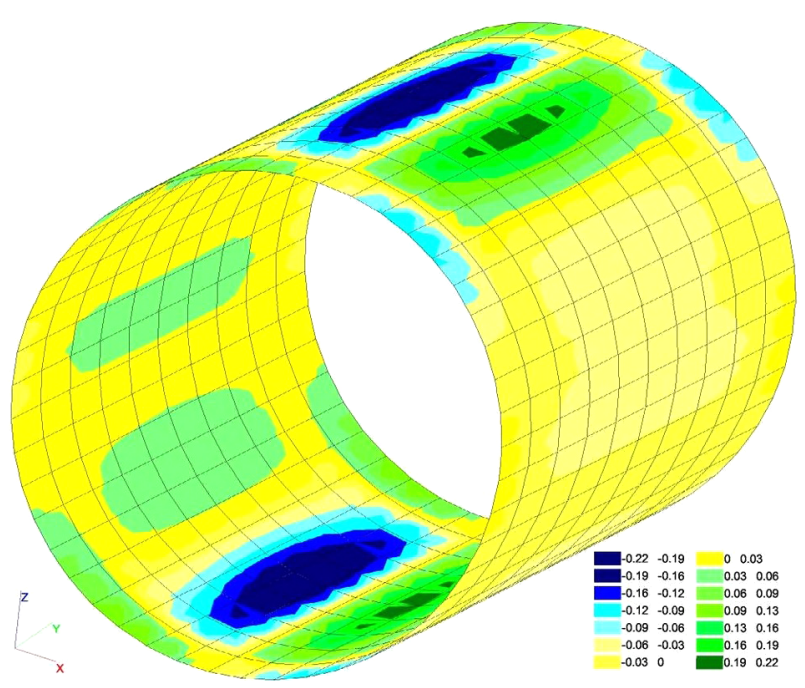

Fig. 8. QX forces in the structure of reinforced lining during concreting, $\mathrm{kN} / \mathrm{m}$

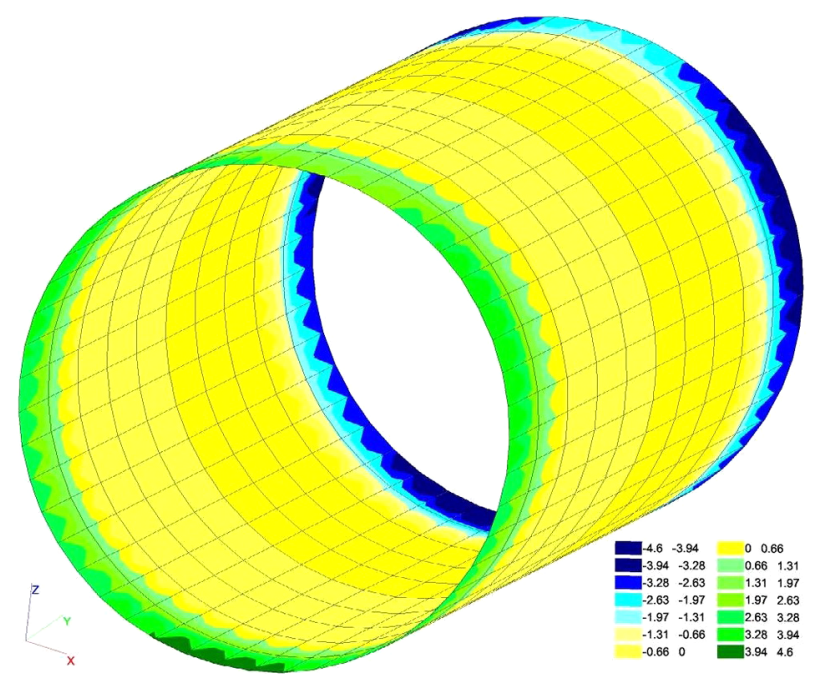

Fig. 9. QY forces in the structure of reinforced lining during concreting, $\mathrm{kN} / \mathrm{m}$ 


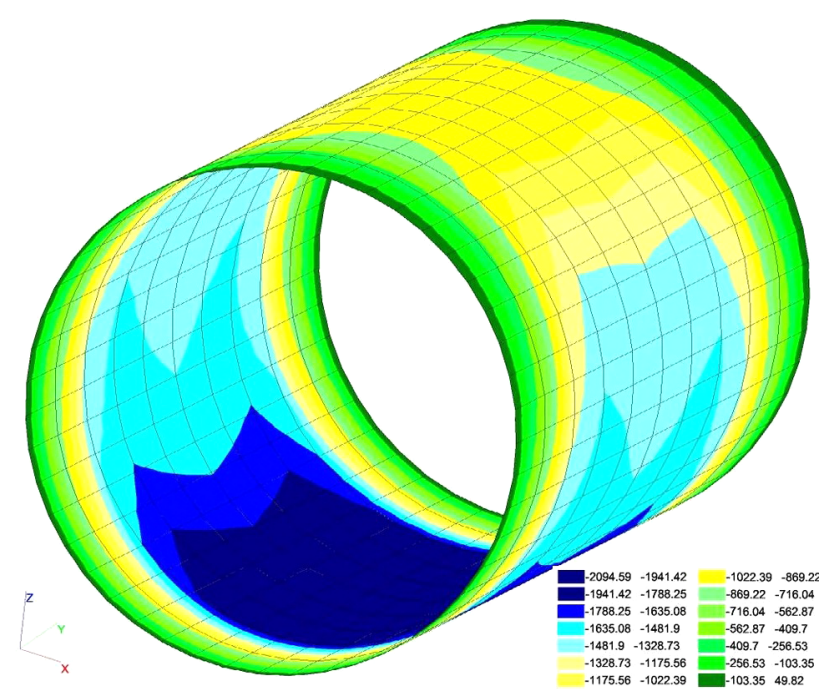

Fig. 10. $Q Y$ forces in the structure of reinforced lining during concreting, $\mathrm{kN} / \mathrm{m}$

The obtained numerical simulation data allowed determining the required parameters of the concrete lining and reinforcement polymer elements for specific geological conditions; the parameters provide long operational capability of the tunnel.

Taking into account modern development of recycling technology for secondary polymer materials, as well as industrial applicability of 3D printing technology for manufacturing protective coating products, the proposed method for sewer tunnel restoration has the following features:

- products of secondary polymer materials are used;

- the protective lining structure is divided into separate elements connected by longitudinal interlocks and spigot-and-socket joints at installation.

The technological cycle of sewer tunnels restoration consists of the following main steps:

1) cleaning and preparation of internal surfaces of tunnel lining;

2) installation of reinforcement in the tube space if it is necessary to reinforce the areas of the tunnel support structure with insufficient bearing capacity;

3) installation of SPCM elements of the protective lining;

4) concreting of the tube space by injecting highslump concrete mix.

Table 2 shows cost indicators for different restoration technologies per 1 running meter of a tunnel.

The advantages of the proposed method of sewer network restoration are as follows:

- the ability to carry out restoration in cramped space;

- manufacturability and ease of installation provided by geometric parameters of the protective lining elements;

- the possibility of varying the thickness of the tube space if it is necessary to strengthen the supporting structure of the tunnel;

- reliability and durability determined by the choice of the polymer products thickness $(20-30 \mathrm{~mm})$, as well
Table 2

Cost indicators of materials and structures used for tunnel restoration

\begin{tabular}{|c|l|l|l|}
\hline No. & \multicolumn{1}{|c|}{ Structure Designation } & Unit & $\begin{array}{l}\text { Cost of } \\
\text { unit* } \\
\text { UAH }\end{array}$ \\
\hline 1 & $\begin{array}{l}\text { Spiro polyethylene pipe } 1724 \mathrm{~mm} \\
\text { in diameter }\end{array}$ & $\begin{array}{l}\text { running } \\
\text { meter }\end{array}$ & 17210 \\
\hline 2 & $\begin{array}{l}\text { Fiberglass pipe } 1600 \mathrm{~mm} \text { in } \\
\text { diameter }\end{array}$ & $\begin{array}{l}\text { running } \\
\text { meter }\end{array}$ & 25140 \\
\hline 3 & $\begin{array}{l}\text { VPCM structures } 1750 \mathrm{~mm} \text { in } \\
\text { diameter }\end{array}$ & $\begin{array}{l}\text { running } \\
\text { meter }\end{array}$ & 2040 \\
\hline
\end{tabular}

${ }^{*}$ Prices of the year 2017

as corrosion resistance of the material exposed to aggressive action which is characteristic of sewer networks;

- the possibility of passing wastewater in the sewage collector through the catheter pipe line during restoration (in case of sufficient drive diameter for blade shields with the diameter of 3.2 and more).

Conclusions and recommendations for further research. The proposed method for restoration of tunnels of urban underground structures using SPCM products meets the requirements mentioned above and can be widely applied at low cost of protective lining, which makes it a competitive alternative to existing methods and provides the opportunity to find a cost effective solution for the problem of restoring operational integrity and reliability of deep underground sewer pipe networks. At present, the proposed method of tunnel restoration is at the stage of pilot implementation in Vodokanal Public Utility in Kharkiv.

\section{References.}

1. Bulgakov, Yu. V., 2015. Investigation of fracture process in the tunnel sewer pipe structure. Naukovyi Visnyk Budivnytstva, 1(79), pp. 79-84.

2. Goncharenko, D.F., Starkova, O.V., Bondarenko, D. N. and Garmash, A.A., 2016. Effective method of repair and renovation of sewer tunnels. Promyslove budivnitstvo i inzhenerni sporudy, 5, pp. 33-36.

3. Starkova, O. V., ed., 2017. Methodological bases of extension of operational life of underground engineering networks. Kharkiv: Raritety Ukrainy.

4. Garmash, A., Bondarenko, D., Zubko, G. and Goncharenko, D., 2016. On renovation of the destroyed tunnel sewer collector in Kharkiv. World Journal of Engineering, 13/1, pp. 72-76.

5. Fisher, W., 2013. Abwasserrohre im Vergleich. $K A$ Korrespondenz Abwasser, Abfall, 9(60), pp. 765-772.

6. Orlov, V. N., Khrenov, K. E. and Bohomolova, Y. O., 2014. Restoration of dilapidated pipelines with precompressed polymer pipes. Vestnik MGSU, 2, pp. 105-113. 7. Schmidt, U. and Bohatsch, A., 2014. Massnahmen gegen Geruch und Korrosion im Mindener Kanalnetz umgesetzt. KA Korrespondenz Abwasser, Abfall, 4(61), pp. 291-298.

8. Kostyuk, T.A., 2015. Developing the tools for judicious choice of the composite with enhanced hydro- 
physical characteristics based on the quality characteristics. Information Processing Systems, 9(134), pp. 46-50. 9. Abramian, S.H. and Potapov, A.A., 2014. Substantiation of economic safety of restoration technology for main pipelines. Vestnik MGSU, 8, pp. 91-95.

10. Yurchenko, V.A. and Brigada, E. V., 2014. Kinetic characteristics of microbiological corrosion of concrete in water disposal networks. Voda i ekologiia: problemy $i$ resheniia, 1(57), pp. 51-61.

\section{Відновлення міських підземних виробок 3 використанням вторинних полімерних композитів}

\section{Д. Ф. Гончаренко ${ }^{1}$, А. В. Убийвовк $\kappa^{1}$, О. О. Гармаш ${ }^{2}$,} М. П. Горох

1 - Харківський національний університет будівництва та архітектури, м. Харків, Україна, e-mail: gonch@kstuca. kharkov.ua

2 - АТ „Південспецатоменергомонтаж“, м. Харків, Україна, e-mail: usaem.ot@ukr.net

3 - КП „Харківводоканал“, м. Харків, Україна, е-mail: hkov_invest@yahoo.com

У даний час підземна інфраструктура великих міст України істотно зношена внаслідок тривалої експлуатації, неефективних рішень щодо захисту конструкцій від агресивного впливу середовища, низької якості матеріалів і будівельно-монтажних робіт при будівництві. Відновлення експлуатаційних характеристик, надійності й довговічності елементів підземної мережі виробок - витратне, технічно та організаційно складне завдання. Проте його вирішення необхідне для запобігання аварій, у тому числі таких, що мають серйозні екологічні та економічні наслідки. Існуючі сучасні технології виконання робіт з відновлення функціонування підземної інфраструктури великих міст, матеріали, що застосовуються для їх відновлення, з різною ефективністю дозволяють вирішувати зазначені задачі. Але разом з тим потреба зниження витрат на відновлення за рахунок саме використання вторинної полімерної сировини, удосконалення технологічних рішень і вирішення проблем екології мегаполісів $є$ актуальним напрямом досліджень.

Мета. 3 урахуванням накопиченого досвіду експлуатації розробити геомеханічні моделі, та на ї основі запропонувати технічні рішення з відновлення експлуатаційної придатності, надійності й довговічності протяжних виробок міської підземної мережі.

Методика. Включає натурні обстеження експлуатованих підземних виробок, експериментальні дослідження полімерного матеріалу в умовах агресивного середовища й чисельне моделювання напружено-деформованого стану захисного облицювання на етапах зведення та експлуатації.

Результати. Свідчать про високу ефективність роботи даного полімерного матеріалу в умовах дії агресивного середовища; чисельне моделювання напружено-деформованого стану захисного обли- цювання дозволяє призначати оптимальні геометричні параметри елементів облицювання в залежності від механічних властивостей матеріалу та особливостей технології зведення облицювання.

Наукова новизна. Запропонована технологія відновлення кріплення протяжних підземних виробок і обгрунтована можливість застосування виробів 3 композитного матеріалу на основі вторинної полімерної сировини.

Практична значимість. Полягає в економічно ефективному вирішенні проблеми відновленні кріплення протяжних підземних виробок (тунелів) за рахунок використання вторинних полімерних матеріалів. Застосування виробів із цих матеріалів при відновленні кріплення протяжних підземних виробок (тунелів) має суттєвий економічний і екологічний ефект, а також забезпечує можливість проведення робіт з відновлення ділянок з обмеженим доступом.

Ключові слова: міські підземні виробки, геомеханічні моделі, руйнування кріплення, захисне облицювання, вторинні композитні полімерні матеріали

\section{Восстановление городских подземных выработок с использованием вторичных полимерных композитов}

\section{Д. Ф. Гончаренко ${ }^{1}$, А. В. Убийвовк $\kappa^{1}$, А. А. Гармаш ${ }^{2}$,} Н. П. Горох ${ }^{3}$

1 - Харьковский национальный университет строительства и архитектуры, г. Харьков, Украина, e-mail: gonch@ kstuca.kharkov.ua

2 - АО „Южспецатомэнергомонтаж“, г. Харьков, УкраиHa, e-mail: usaem.ot@ukr.net

3 - КП „Харьковводоканал“, г. Харьков, Украина, e-mail: hkov_invest@yahoo.com

В настоящее время подземная инфраструктура крупных городов Украины существенно изношена в результате длительной эксплуатации, неэффективных решений по защите конструкций от агрессивного воздействия среды, низкого качества материалов и строительно-монтажных работ при строительстве. Восстановление эксплуатационных характеристик, надежности и долговечности элементов подземной сети выработок - затратная, технически и организационно сложная задача. Однако ее решение необходимо для предотвращения аварий, в том числе имеющих серьезные экологические и экономические последствия. Существующие современные технологии выполнения работ по восстановлению функционирования подземной инфраструктуры крупных городов, материалы, применяемые для их восстановления, с разной эффективностью позволяют решать указанные задачи. Но вместе с тем потребность снижения затрат на восстановление за счет использования полимерного сырья, совершенствования технологических решений и решения проблем экологии мегаполисов является актуальным направлением исследований.

Цель. С учетом накопленного опыта эксплуатации разработать геомеханические модели, и на их 
основе предложить технические решения по восстановлению эксплуатационной пригодности, надежности и долговечности протяженных выработок городской подземной сети.

Методика. Включает натурные обследования эксплуатируемых подземных выработок, экспериментальные исследования полимерного материала в условиях агрессивной среды и численное моделирование напряженно-деформированного состояния защитной облицовки на этапах возведения и эксплуатации.

Результаты. Свидетельствуют о высокой эффективности работы рассматриваемого полимерного материала в условиях воздействия агрессивной среды; численное моделирование напряженно-деформированного состояния защитной облицовки позволяет назначать оптимальные геометрические параметры элементов облицовки в зависимости от механических свойств материала и особенностей технологии устройства облицовки.

Научная новизна. Предложена технология восстановления крепи протяженных подземных выра- боток и обоснована возможность применения композитного материала на основе вторичного полимерного сырья.

Практическая значимость. Заключается в экономически эффективном решении проблемы восстановления крепи протяженных подземных выработок (тоннелей) за счет использования изделий из вторичных полимерных материалов. Применение изделий из этих материалов при восстановлении крепления протяженных подземных выработок (тоннелей) имеет существенный экономический и экологический эффект, а также обеспечивает возможность проведения работ по восстановлению участков с ограниченным доступом.

Ключевые слова: городские подземные выработ$\kappa и$, геомеханические модели, разрушение крепи, защзитная облицовка, вторичные композитные полимерные материаль

Рекомендовано до публікації докт. техн. наук I.А.Менейлюком. Дата надходження рукопису 21.12.17. 